\title{
Effect of inoculants in corn silage on dry matter digestibility, ingestive behavior, performance and carcass of heifers
}

\section{Efeito de inoculantes na silagem de milho sobre o comportamento ingestivo, digestibilidade da matéria seca, desempenho e características da carcaça de novilhas}

Tânia Mara Becher Ribas ${ }^{1}$; Mikael Neumann²; Egon Henrique Horst ${ }^{3 *}$; Fernando Braga Cristo4; Eduardo Mateus Moresco4; Eduardo Rodrigues de Almeida ${ }^{4}$

\section{Highlights}

The 11CFT and 11C33 inoculants in corn silage does not affect the ingestive behavior. The 11CFT and 11C33 inoculants promotes improvements on the apparent digestibility. The 11CFT inoculant was able to increase the carcass gain.

\begin{abstract}
We aim to evaluate inoculants with different strains of lactic acid bacteria (LAB) in corn silage on ingestive behavior, apparent digestibility of diet, performance and carcass traits of heifers. The treatments were: corn silage without inoculant (control); with 11CFT inoculant (strains of Lactobacillus buchneri and Lactobacillus casei) and with 11C33 inoculant (Lactobacillus buchneri, Lactobacillus plantarum and Enterococcus faecium) with six repetitions each. Ingestive behavior, weight gain and daily dry matter intake was not affected by the use of inoculants in corn silage. The apparent digestibility of diet was higher to silage with 11C33 inoculant, not differing from the diet with silage with $11 \mathrm{CFT}$ (73.30\% and $71.99 \%$, respectively). The animals fed silage inoculated with $11 \mathrm{CFT}$ obtained greater values of carcass gain and average daily carcass gain $(86.33 \mathrm{~kg}$ and $0.833 \mathrm{~kg} \mathrm{day}^{-1}$, respectively). The use of these inoculants in corn silage shows promising results regarding the gain of animals in feedlot.
\end{abstract}

Key words: Biological additive. Apparent digestibility. Carcass gain. Weight gain. Lactobacillus buchneri.

1 Master Science in Veterinary Sciences, Parana Midwestern State University, UNICENTRO, Guarapuava, PR, Brazil. E-mail: taniamarabecherribas@hotmail.com

2 Professor of Department of Veterinary Medicine, UNICENTRO, Guarapuava, PR, Brazil. E-mail: neumann.mikael@ hotmail.com

${ }^{3}$ Doctor in Animal Science, State University of Londrina, UEL, Londrina, PR, Brazil. E-mail: egonhh@yahoo.com.br

${ }^{4}$ Students of Master Science in Veterinary Sciences, UNICENTRO, Guarapuava, PR, Brazil. E-mail: fernandobragacristo@ gmail.com; eduardomateusmoresco@gmail.com; eduardo_tra@hotmail.com

* Author for correspondence

Received: July 07, 2020 - Approved: Nov. 17, 2020 


\section{Resumo}

Objetivamos avaliar inoculantes com diferentes espécies de bactéria ácido lática (BAL) na silagem de milho sobre o comportamento ingestivo, digestibilidade aparente da dieta, desempenho e características de carcaça de novilhas confinadas. Os tratamentos foram: silagem de milho sem inoculante (controle); com inoculante 11CFT (cepas de Lactobacillus buchneri e Lactobacillus casel) e com inoculante 11C33 (Lactobacillus buchneri, Lactobacillus plantarum e Enterococcus faecium) com seis repetições cada. 0 comportamento ingestivo, ganho de peso e consumo diário de matéria seca não foram afetados pelo uso de inoculantes na silagem de milho. A digestibilidade aparente da dieta foi maior para silagem com inoculante 11C33, não diferindo da dieta com silagem com 11CFT (73,30\% e 71,99\%, respectivamente). Os animais alimentados com silagem inoculada com 11CFT obtiveram maiores valores de ganho de carcaça e ganho médio diário de carcaça (86,33 kg e 0,833 kg dia-1, respectivamente). O uso desses inoculantes na silagem de milho mostra resultados promissores em relação ao ganho de animais em confinamento.

Palavras-chave: Aditivo biológico. Digestibilidade aparente. Ganho de carcaça. Ganho de peso. Lactobacillus buchneri.

\section{Introduction}

The forage conservation method is based on the conversion of soluble carbohydrates into organic acids. However, silages with inadequate fermentation, with low concentrations of these acids, can result in feed with low nutritional value and poor animal performance (A. S. Oliveira et al., 2017). Bacterial inoculants are often used to promote desirable fermentation patterns. The use of homofermentative lactic acid bacteria, such as Lactobacillus casei and Enterococcus faecium, accelerate lactic acid production and promote a rapid decline in the $\mathrm{pH}$ of medium, but this predominance of lactic acid can lead to great deterioration of nutrients by yeast after opening the silo (Lynch, Bahh, \& Beauchemin, 2015).

According to Tabacco, Righi, Quarantelli and Borreani (2011), predominance of homofermentative bacteria does not always improve the preservation of nutrients compared to untreated silages, especially in corn silage. Thus, inoculants containing
Lactobacillus buchneri, a strain with potential for acetic acid production, is frequently used. The antifungal action of acetic acid assists in the control of fungi and yeasts during the period of aerobic exposure (Borreani, Tabacco, Schmidt, Holmes, \& Muck, 2018), improving the preservation of silage nutrients.

It's aiming to improve the production of acetic acid in silage, some commercial inoculants also include facultative heterofermentative bacteria. This group contains several strains of great importance, the most known is Lactobacillus plantarum. However, Li and Nishino (2011) emphasize that this combination of different lactic acid bacteria can modify the results found during the fermentation process.

In a meta-analysis, A. S. Oliveira et al. (2017) point to promising effects of lactic acid bacteria inoculation on the performance of dairy cows, even without improving the digestibility of silage dry matter. Considering all the benefits provided by the bacterial action, inoculated silages can improve the 
performance of feedlot cattle (Fugita et al., 2012), but studies related to this are still scarce requiring tests in conditions close to field reality. Further tests are also needed to prove that the addition of these inoculants does not cause ingestive behavior changes in cattle (Ribeiro et al., 2011) and the benefits in dry matter intake of cattle fed inoculated silages.

The objective of this study was to evaluate the effects of inoculants with different strains of lactic acid bacteria in corn silage on ingestive behavior, apparent digestibility of the diet, performance and carcass traits of feedlot heifers.

\section{Material and Methods}

The experimental procedures were previously submitted to the Committee for Ethics in Animal Experimentation (CEUA/ UNICENTRO), and approved for execution under Opinion 035/2016 on October 7, 2016.

The corn hybrid used for production silages was $\mathrm{P} 2866 \mathrm{H}$, harvested at the $\mathrm{R} 5$ stage of maturity. The inoculants were applied diluted in water, according to the manufacturer's instructions, to obtain a concentration of 20 $\times 10^{10}$ Colony Forming Unit (CFU) $\mathrm{g}^{-1}$ of the

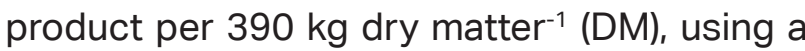
variable pressure sprayer. The application was made during the corn harvest, using a spray nozzle located at the of the forage machine, seeking the uniform distribution of the product.

We evaluated the ingestive behavior, diet digestibility, performance and carcass traits of feedlot heifers receiving corn silage inoculated with different strains of lactic acid bacteria, thus constituting three treatments: corn silage without inoculant (control); corn silage with Pioneer ${ }^{\circledR} 11 \mathrm{CFT}$ inoculant; and corn silage with Pioneer $^{\circledR} 11 \mathrm{C} 33$ inoculant.

The Pioneer ${ }^{\circledR} 11 \mathrm{CFT}$ inoculant consists of strains of Lactobacillus buchneri $\left(1.1 \times 10^{11}\right.$ CFU g $\left.{ }^{-1}\right)$ and Lactobacillus casei $\left(1.1 \times 10^{11} \mathrm{CFU}\right.$ $\left.\mathrm{g}^{-1}\right)$. The Pioneer ${ }^{\circledR} 11 \mathrm{C} 33$ inoculant consists of strains of Lactobacillus buchneri $\left(10^{11} \mathrm{CFU} \mathrm{g}^{-1}\right)$, Lactobacillus plantarum $\left(1.1 \times 10^{11} \mathrm{CFU} \mathrm{g}^{-1}\right)$ and Enterococcus faecium $\left(1 \times 10^{10} \mathrm{CFU} \mathrm{g}^{-1}\right)$.

The material collected from each treatment was stored in trench silos with 15 $\mathrm{m}$ length, $4 \mathrm{~m}$ width and $1.2 \mathrm{~m}$ height. Their opening occurred simultaneously at 160 days after ensiling. Samples of the three corn silage treatments and the concentrate used to formulate the diets were taken to a forced air oven at $55^{\circ} \mathrm{C}$ for 72 hours to determine the partial dry matter. The pre-dried samples were ground in a Wiley mill with a $1 \mathrm{~mm}$ sieve and subsequently analyzed for contents of mineral matter (MM) (MM; method 938.08), ether extract (EE) (EE; method 920.85) and crude protein (CP) by the micro Kjeldahl method (CP; method 981.10), according to Association of Official Analytical Chemists [AOAC] (1990). The content of neutral detergent fiber (aNDF) was obtained according to Van Soest, Robertson and Lewis (1991) with thermostable alphaamylase, and acid detergent fiber (ADF) and lignin, according to Goering and Van Soest (1970). To determine the total dry matter, the samples were taken to a forced air oven at 105 ${ }^{\circ} \mathrm{C}$ for 16 hours (AOAC, 1990).

The diets of feedlot heifers consisted of the three corn silages at a constant ratio of $50 \%$ forage and $50 \%$ concentrate, on a dry matter basis. Table 1 lists the chemical composition of the feed components of the experimental rations used in animal feeding. 
Table 1

Chemical composition of ingredients composing the experimental rations

\begin{tabular}{|lcccc}
\multirow{2}{*}{\multicolumn{1}{c}{ Parameter }} & \multicolumn{3}{c}{ Corn Silage } & Concentrate \\
\cline { 2 - 4 } Dry matter, \% NM & Control & 11CFT & 11 C33 & \\
Mineral matter, \% DM & 39.49 & 38.41 & 39.04 & 90.30 \\
\hline Crude Protein, \% DM & 2.50 & 2.23 & 2.36 & 6.36 \\
Neutral detergente fiber, \% DM & 5.78 & 5.57 & 6.21 & 20.20 \\
\hline Acid detergente fiber, \% DM & 41.00 & 43.17 & 46.72 & 31.46 \\
\hline Lignin, \% DM & 26.86 & 25.87 & 27.02 & 23.90 \\
\hline Total digestible nutrients, \% DM & 4.64 & 4.49 & 4.64 & 4.73 \\
\hline
\end{tabular}

Thirty-six $1 / 2$ Angus $\times$ Nellore heifers, with an average initial weight of $310 \pm 10 \mathrm{~kg}$ and an average 12 months old, came from the same farm and were previously dewormed. The animals were housed in 18 half-roofed pens, with area of $15 \mathrm{~m}^{2}$ each $(2.5 \mathrm{~m} \times 6.0 \mathrm{~m})$, with a concrete feeder measuring $2.30 \mathrm{~m}$ long, 0.60 $\mathrm{m}$ wide and $0.35 \mathrm{~m}$ depth and a metal drinking fountain controlled by an automatic float. The distribution of animals in the experimental units was carried out based on body weight and body condition.

The animals were subjected to a 10-day adaptation period to the diets and facilities. The experiment lasted 105 days, and animals were weighed on the first day, followed by three weighings every 28 days, and a last one after 21 days. The animals were supplied with feed twice a day (06h00 and 17h30) and intake was recorded daily through the difference in weight between the amount offered and leftovers from the previous day. The supply was carried out aiming at ad libitum offer.

At the end of the first and third feedlot evaluation periods, animals were observed for 48 uninterrupted hours, for analysis of ingestive behavior, starting at 12 noon on the first day and ending at 12 noon on the third day. The observations were made by six observers per shift, for 48 hours, in a rotation system every six hours, with readings taken at regular intervals of three minutes. Ingestive behavior data, represented by idle, rumination, water and feed intake activities, were expressed in hours day ${ }^{-1}$. We also monitored, following the same methodology, the frequency of the occurrence of activities of feeding, watering, defecation, urination and non-ingestive oral behavior, expressed in number of times day $^{-1}$. During this same period, all solid excretion was collected to determine fecal output and apparent digestibility of the diet. Homogeneous samples of the feces produced were collected and dried in a forced air oven at $55^{\circ} \mathrm{C}$, and after corrected for total dry matter at $105^{\circ} \mathrm{C}$.

During analysis of ingestive behavior, feces in each pen were scored by visual observation. The feces scores ranged from 1 to 6 , being: 1 : watery feces, no consistent; 2 : watery feces, not very consistent, with small piles of up to $2.5 \mathrm{~cm}$; 3 : intermediate feces with concentric ring and 3 to $4 \mathrm{~cm}$ liquid pile; 4 : little liquid feces with concentric rings and a pile of 
more than $5 \mathrm{~cm}$; 5 : dryer feces, no concentric ring and pile of more than $5 \mathrm{~cm}$; 6 : hardened or dried feces, based on the methodology adapted from Ferreira et al. (2013).

Before each weighing at the end of each period, the animals were fasted for solids for 12 hours, allowing the evaluation of body weight (BW), average dry matter intake, expressed in $\mathrm{kg}$ animal day ${ }^{-1}$ (DMl, $\mathrm{Kg}_{\text {day }}{ }^{-1}$ ), average dry matter intake, expressed as a percentage of body weight (DMI, \% body weight), average daily weight gain (ADG, $\mathrm{kg}$ day $^{-1}$ ) and feed efficiency (FE, kg BW kg DM-1), obtained by the ratio of average daily weight gain to average daily dry matter intake (DMI $\left.\mathrm{ADG}^{-1}\right)$.

Attheend of the period, theanimalswere weighed before sent to the slaughterhouse, obtaining the farm weight. The carcass gain in the feedlot period (ACG) expressed in $\mathrm{kg}$, was obtained by the difference between the hot carcass weight at slaughter and the initial body weight of the animals under theoretical carcass yield of $50 \%$. Taking the 105-day period in the feedlot as a base, the average

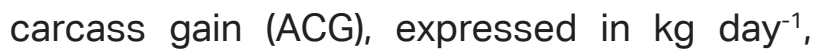
was also calculated, which is obtained by the ratio of CG to BW, as well as the efficiency in converting consumed dry matter into carcass (ECC), expressed in kg DM kg carcass $^{-1}$ and the efficiency in converting weight gain into carcass, which is obtained by the ratio of ACG to ADG (ACG $\div A D G$ ), expressed as a percentage. Hot carcass weights were used for the calculations.

Carcass length was measured, which is the distance between the medial cranial edge of the pubic bone and the medial cranial edge of the first rib; arm length, which is the distance between the tuberosity of the olecranon and the radiocarpal joint; arm circumference, obtained in the median region of the arm by surrounding it with a measuring tape; and the thigh thickness, measured with a compass, perpendicular to the carcass length, taking the greatest distance between the cut that separates the two half carcasses and the lateral thigh muscles.

At the time of slaughter, the characterization of body parts that are not part of the carcass of the slaughtered heifers was also carried out by measuring the weights of the following components: head, tongue, tail, skin and paw (external components); and heart, kidneys, liver, lungs, spleen, empty rumen-reticulum, full rumen-reticulum and full intestines (vital organs).

The data obtained for each variable were tested for normality by the "ShapiroWilk" test (PROC UNIVARIATE) and for homogeneity by the "Bartlett" test (PROC GLM). The experimental design used to animal performance and carcass characteristics was randomized blocks, with three treatments and six repetitions, with each statistical repetition being the average of a pen with two animals. The data collected for each variable were analyzed using the General linear model procedure (PROC GLM) and subjected to Tukey's test to compare multiple averages at $5 \%$ significance using the SAS software (v. 9.2; SAS Institute Inc., Cary, NC), according to the model:

$$
Y_{i j k}=\mu+I_{i}+B_{j}+E_{i j k}
$$

where:

$$
\mathrm{Y}_{\mathrm{ijkl}}=\text { dependent variables; } \mu=\text { Overall }
$$
mean; $I_{i}=$ Effect of the inoculant " $\mathrm{i}$ ", being $1=$ control diet, $2=$ diet with silage treated with inoculant $11 \mathrm{CFT}$, and $3=$ diet with silage treated with inoculant 11C33; $B_{j}=$ Effect of block "j", 1...6; $E_{i j k}=$ Residual random effect. 
The experimental design used to ingestive behavior and apparent digestibility was also the randomized blocks, composed by six treatments in a $3 \times 2$ factorial scheme, being three treatments and two evaluation periods, with six repetitions, where each repetition corresponded to a pen with two animals. Subsequently, the results were submitted were analyzed using the General linear model procedure (PROC GLM) and subjected to Tukey's test to compare multiple averages at $5 \%$ significance using the SAS software (v. 9.2; SAS Institute Inc., Cary, NC), according to the model:

$$
Y_{i j k}=\mu+I_{1}+B_{J}+P_{k}+(I \times P)_{i k}+E_{i j k l}
$$

where:

$$
\mathrm{Y}_{\mathrm{ijkl}}=\text { dependent variables; } \mu=\text { Overall }
$$

mean; $I_{i}=$ Effect of the inoculant " $\mathrm{i}$ ", being $1=$ control diet, 2 = diet with silage treated with inoculant 11CFT, and $3=$ diet with silage treated with inoculant $11 \mathrm{C} 33 ; B_{j}=$ Effect of block "j", 1...6; $P_{k}=$ Effect of the confinement period of order " $k$ ", being 1 = first period and 2 $=$ third period; $(\mid \times P)_{i k}=$ Effect of the interaction between innoculant and "ik" containment period; $\mathrm{E}_{\mathrm{ijk}}=$ Residual random effect.

\section{Results and Discussion}

Data on ingestive behavior in Table 2 show that the times spent in activities of feed consumption, water consumption, rumination and idle, in the general average, were not changed $(P>0.05)$ with the use of inoculant in corn silage. These results can be considered satisfactory, since the main objectives of silage inoculation is the chemical and sanitary preservation of the silage, without any risk to animal health and/or deviations in feeding behavior.

In the analysis of the initial and final feedlot phase, the times spent in the consumption of feed and water were similar, while for the rumination and idle times there was a change $(P<0.05)$, regardless of the use of inoculants in corn silage. In the initial phase, the animals spent a shorter time on rumination (5.4 against 6.4 hours day $^{-1}$ ) and longer in idle (15.2 against 14.2 hours day $^{-1}$ ) compared to the final feedlot phase.

The ingestive behavior expressed in the frequency of activities in number of times per day (Table 3), likewise, showed no significant difference between treatments. For the evaluation period, there was a difference $(P<0.05)$ in the number of feedings $(21.4$ and 18.8 times day $\left.^{-1}\right)$, water intake (8.9 and 6.6 times day $\left.^{-1}\right)$ and in non-ingestive oral behavior (5.7 and 3.3 times day $^{-1}$ ), always higher in the initial period. Such behavior can be due to the prolonged adaptation, either to the environment and also to the animal belonging to the same pen, which can generate strangeness on the part of both, causing less routine behaviors (Missio et al., 2010). 


\section{Table 2}

Feeding behavior (hours day ${ }^{-1}$ ) of heifers finished in feedlot with the use of maize silage treated with different bacterial inoculants

\begin{tabular}{|c|c|c|c|}
\hline \multirow{2}{*}{ Experimental diet } & \multicolumn{2}{|c|}{ Feedlot phase } & \multirow{2}{*}{ Average } \\
\hline & $1^{\text {st }}$ period (initial) & $3^{\text {rd }}$ period (final) & \\
\hline & \multicolumn{3}{|c|}{ Feed intake, hours day ${ }^{-1}$} \\
\hline Control & 3.1 & 3.1 & $3.1 \mathrm{~A}$ \\
\hline $11 \mathrm{CFT}$ & 3.0 & 3.6 & $3.3 \mathrm{~A}$ \\
\hline $11 \mathrm{C} 33$ & 3.2 & 3.2 & $3.2 \mathrm{~A}$ \\
\hline \multirow[t]{2}{*}{ Mean } & $3.1 \mathrm{a}$ & $3.3 \mathrm{a}$ & \\
\hline & \multicolumn{3}{|c|}{ Water intake, hours day ${ }^{-1}$} \\
\hline Control & 0.2 & 0.2 & $0.2 \mathrm{~A}$ \\
\hline $11 \mathrm{CFT}$ & 0.2 & 0.2 & $0.2 \mathrm{~A}$ \\
\hline $11 \mathrm{C} 33$ & 0.2 & 0.2 & $0.2 \mathrm{~A}$ \\
\hline \multirow[t]{2}{*}{ Mean } & $0.2 \mathrm{a}$ & $0.2 \mathrm{a}$ & \\
\hline & \multicolumn{3}{|c|}{ Rumination, hours day ${ }^{-1}$} \\
\hline Control & 5.0 & 6.1 & $5.5 \mathrm{~A}$ \\
\hline 11CFT & 5.7 & 6.1 & $5.9 \mathrm{~A}$ \\
\hline $11 \mathrm{C} 33$ & 5.4 & 6.6 & $6.0 \mathrm{~A}$ \\
\hline \multirow[t]{2}{*}{ Mean } & $5.4 \mathrm{~b}$ & $6.4 \mathrm{a}$ & \\
\hline & \multicolumn{3}{|c|}{ Idleness, hours day ${ }^{-1}$} \\
\hline Control & 15.5 & 14.6 & $15.0 \mathrm{~A}$ \\
\hline 11CFT & 15.0 & 13.9 & $14.5 \mathrm{~A}$ \\
\hline $11 C 33$ & 15.0 & 13.9 & $14.5 \mathrm{~A}$ \\
\hline Mean & $15.2 \mathrm{a}$ & $14.2 b$ & \\
\hline
\end{tabular}

Means, followed by lower case in the line differ among them by the Tukey Test at 5\%.

Means, followed by capital letter in the column differ among them by the Tukey Test at $5 \%$.

The time spent and the number of times for the activities that differed are inversely proportional, which seems obvious, however, the authors have not reached a reliable conclusion as to why the animals extended the time spent in rumination and decreased the time in idle, with the advance of feedlot finishing days. 


\section{Table 3}

Feeding behavior expressed by activities frequency (times day-1 ${ }^{-1}$, of heifers finished in feedlot with the use of maize silage with different bacterial inoculants

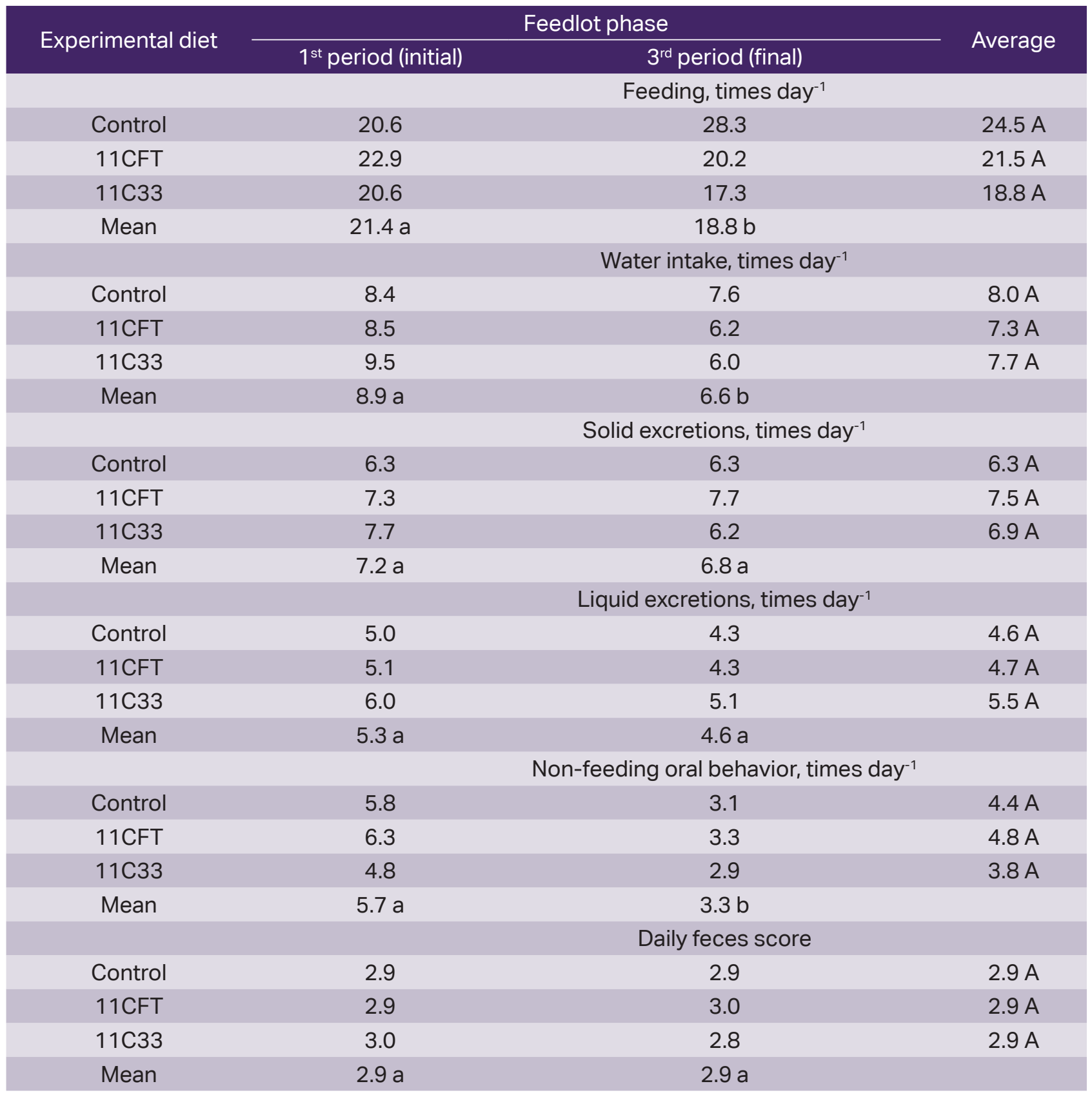

Means, followed by lower case in the line differ among them by the Tukey Test at $5 \%$.

Means, followed by capital letter in the column differ among them by the Tukey Test at $5 \%$. 
Bacterial inoculation in silage did not promote significant improvements for weight gain, dry matter intake per day or as a percentage of body weight, and feed efficiency (Table 4), presenting average values at 105 days of finishing of $1.200 \mathrm{~kg} \mathrm{day}^{-1}, 9.17$ $\mathrm{kg} \mathrm{day}^{-1}, 2.40 \%$ body weight and $0.131 \mathrm{~kg}$ $\mathrm{kg}^{-1}$, respectively. The lack of differences in the chemical composition between the control silage and the inoculated silages may be the explanation for the similar results of the test of feeding and animal performance. According to Oliveira, Neumann, Oliboni, Gobetti and Faria (2011), biological inoculants have their efficiency on corn silage damaged when it is exposed in non-ideal handling conditions, such as long time for silo sealing and hygiene failure, which is not the case in the present study. Based on the management used for making and checking the specific mass, all silages had adequate fermentation, promoting equivalent quality.

\section{Table 4}

\section{Performance of heifers fed diets containing corn silages with different bacterial inoculants}

\begin{tabular}{|c|c|c|c|c|c|c|}
\hline \multirow{2}{*}{ Days in feedlot } & \multicolumn{3}{|c|}{ Experimental diets } & \multirow{2}{*}{ Average } & \multirow{2}{*}{ SEM } & \multirow{2}{*}{$P$-value } \\
\hline & Control & $11 \mathrm{CFT}$ & $11 \mathrm{C} 33$ & & & \\
\hline \multicolumn{7}{|c|}{$A D G, \mathrm{~kg} \mathrm{day}^{-1}$} \\
\hline 0 to 28 days & 1.226 & 1.235 & 1.107 & 1.189 & 0.0431 & 0.8105 \\
\hline 0 to 56 days & 0.952 & 1.101 & 1.018 & 1.107 & 0.0346 & 0.5662 \\
\hline 0 to 84 days & 1.360 & 1.363 & 1.238 & 1.178 & 0.0206 & 0.0600 \\
\hline 0 to 105 days & 1.250 & 1.230 & 1.321 & 1.200 & 0.0200 & 0.2465 \\
\hline \multicolumn{7}{|c|}{ DMI, kg day ${ }^{-1}$} \\
\hline 0 to 28 days & 8.40 & 8.95 & 8.68 & 8.68 & 0.1410 & 0.0519 \\
\hline 0 to 56 days & 8.57 & 9.58 & 8.75 & 8.82 & 0.1572 & 0.0925 \\
\hline 0 to 84 days & 9.12 & 9.99 & 9.25 & 9.03 & 0.1443 & 0.0535 \\
\hline 0 to 105 days & 9.50 & 9.12 & 9.26 & 9.17 & 0.1405 & 0.0566 \\
\hline \multicolumn{7}{|c|}{ DMI, \% BW } \\
\hline 0 to 28 days & 2.52 & 2.63 & 2.59 & 2.58 & 0.0407 & 0.1572 \\
\hline 0 to 56 days & 2.36 & 2.57 & 2.40 & 2.51 & 0.0428 & 0.2847 \\
\hline 0 to 84 days & 2.30 & 2.45 & 2.33 & 2.46 & 0.0382 & 0.2396 \\
\hline 0 to 105 days & 2.22 & 2.27 & 2.16 & 2.40 & 0.0353 & 0.2682 \\
\hline \multicolumn{7}{|c|}{$\mathrm{FE}, \mathrm{kg}$ of BW $\mathrm{kg}$ of DM } \\
\hline 0 to 28 days & 0.148 & 0.138 & 0.127 & 0.138 & 0.0059 & 0.8525 \\
\hline 0 to 56 days & 0.111 & 1.114 & 0.116 & 0.126 & 0.0038 & 0.9610 \\
\hline 0 to 84 days & 0.149 & 0.136 & 0.134 & 0.130 & 0.0024 & 0.6012 \\
\hline 0 to 105 days & 0.133 & 0.125 & 0.144 & 0.131 & 0.0024 & 0.5552 \\
\hline
\end{tabular}

ADG: Average daily gain; DMI: Dry matter intake; FE: Feed efficiency; BW: Body weight; DM: Dry matter. 
Studies such as those by Nkosi, Meeske, Langa and Thomas (2011) and Weinberg et al. (2007) point to positive results from biological inoculation of corn silage on in vitro ruminal digestibility and apparent digestibility in sheep, respectively. However, the diversity of strains used and the scarcity of animal performance results in the literature hinder better conclusions (Filya \& Sucu, 2010).
In Table 5, it is possible to observe that the apparent digestibility of the diet containing silages with different inoculants was higher when containing the 11C33 inoculant, not differing, however, from the diet with silage with 11 CFT $(73.30 \%$ and $71.99 \%$, respectively).

\section{Table 5}

Fecal output based on natural and dry matter, in kg day $^{-1}$, dry matter content of feces and dry matter apparent digestibility of the diet

\begin{tabular}{|ccccccc|}
\hline \multirow{2}{*}{ Parameter } & \multicolumn{3}{c}{ Experimental diets } & \multirow{2}{*}{ Average } & SEM & P-value \\
\cline { 2 - 4 } & Control & 11CFT & $11 \mathrm{C} 33$ & & & \\
\hline Fecal output, kg of NM day ${ }^{-1}$ & 13.57 & 13.94 & 12.99 & 13.50 & 0.4762 & 0.3767 \\
\hline Dry matter of feces, \% & 18.95 & 18.57 & 19.28 & 18.93 & 0.2137 & 0.8681 \\
\hline Fecal output, kg of DM day ${ }^{-1}$ & 2.57 & 2.59 & 2.42 & 2.53 & 0.0780 & 0.2864 \\
\hline Apparent digestibility of DM, \% & $70.58 \mathrm{~b}$ & $71.99 \mathrm{ab}$ & $73.30 \mathrm{a}$ & 71.96 & 0.6190 & 0.0154 \\
\hline
\end{tabular}

NM: Natural matter; DM: Dry matter.

Means, followed by lower case in the line differ among them by the Tukey Test at 5\%.

Silva et al. (2005) detected better in vitro dry matter digestibility of corn silages with inoculant containing Enterococcus faecium, Lactobacillus plantarum and Pediococcus acidilactici than control silage. The authors relate this improvement to changes in the fiber components of silage, however, this effect is not completely clear, since lactic acid bacteria do not degrade components of the cell wall or any other component that limits digestibility. Meanwhile, Abdel-Rahman, Tashiro and Sonomoto (2011) clarify that the acidification of the medium provided by lactic acid bacteria favors the hydrolysis of hemicellulose, which can lead to a greater degradation of this fraction by ruminal microorganisms.
The dry matter content of feces and the fecal output, both in dry matter and natural matter, did not change $(P>0.05)$ due to the application of bacterial inoculant in corn silage.

Data in Table 6 show significant interference from the use of inoculant in corn silage in relation to the parameters of carcass gain at the end of the confinement of heifers (CG) and average daily carcass gain (ACG), where animals fed silage with 11CFT inoculant obtained the highest yields $(86.33 \mathrm{~kg}$ and 0.833 $\mathrm{kg} \mathrm{day}^{-1}$, respectively). The silage inoculated with 11C33 resulted in values below those of silage with $11 \mathrm{CFT}$, and similar to control silage, contrasting the apparent digestibility data in Table 6. 
Table 6

Carcass gains of heifers fed diets containing corn silages with different bacterial inoculants

\begin{tabular}{|c|c|c|c|c|c|c|}
\hline \multirow{2}{*}{ Parameter } & \multicolumn{3}{|c|}{ Experimental diets } & \multirow{2}{*}{ Average } & \multirow{2}{*}{ SEM } & \multirow{2}{*}{ P-value } \\
\hline & Control & $11 \mathrm{CFT}$ & $11 \mathrm{C33}$ & & & \\
\hline $\mathrm{CG}, \mathrm{kg}$ & $77.10 \mathrm{~b}$ & 86.33 a & $76.32 \mathrm{~b}$ & 79.92 & 2.5996 & 0.0130 \\
\hline ACG, kg day ${ }^{-1}$ & $0.734 \mathrm{~b}$ & $0.833 \mathrm{a}$ & $0.727 b$ & 0.761 & 0.0084 & 0.0130 \\
\hline ACG ADG-1, \% & 61.46 & 66.86 & 62.40 & 63.57 & 0.2462 & 0.2814 \\
\hline ECC, $\mathrm{kg}$ of DM kg of carcass ${ }^{-1}$ & 12.17 & 11.73 & 12.36 & 12.09 & 0.9634 & 0.8795 \\
\hline
\end{tabular}

CG: Carcass gain during the confined period; ACG: Average carcass gain expressed in kg day ${ }^{-1}$ : ACG ADG $^{-1}$ : Efficiency in converting weight gain into carcass ECC: Efficiency in converting consumed dry matter into carcass.

Means, followed by lower case in the line differ among them by the Tukey Test at $5 \%$.

It is important to note that the $\mathrm{CG}$ can become a more plausible measure for conclusions from the feedlot farmers than the ADG (Table 4), since the small daily differences in weight detected in association with the small differences in the animals initial weight, which are not significant, can be noticed in this index, revealing profitability or not of the batch.

Regarding the mean values of the efficiency in converting consumed dry matter into carcass ( $A C G A^{-1}$ ) and the efficiency in converting weight gain into carcass (ECC), these did not change ( $P>0.05$ ), presenting averages of $63.57 \%$ and $12.09 \mathrm{~kg}$ DM kg carcass $^{-1}$, respectively.

It cannot be inferred that the highest body weight at slaughter and hot carcass of animals fed silage with 11CFT inoculant (451.8 $\mathrm{kg}$ and $241.2 \mathrm{~kg}$, respectively; Table 7) was at the expense of using the inoculant, as seen that there were no differences for daily weight gain. These differences may be related to the initial weight of the animals in this treatment, even if the distribution in the experiment was made aiming at the smallest possible standard deviation ( $\pm 10 \mathrm{~kg})$.

As expected (Lynch et al., 2015), the use of bacterial inoculant applied to silage did not promote changes in parameters related to carcass yield, fat thickness, carcass length, thigh thickness, arm length and arm circumference, with average values of 52.8 \%; $6.28 \mathrm{~mm} ; 124.3 \mathrm{~cm} ; 17.9 \mathrm{~cm} ; 35.7 \mathrm{~cm}$ and $38.4 \mathrm{~cm}$, respectively. Regardless of the treatment, the animals showed carcass yield and subcutaneous fat cover that met the requirements imposed by the slaughterhouse (minimum $220 \mathrm{~kg}$ and 3 to $6 \mathrm{~mm}$, respectively).

As no difference was detected for daily weight gain, but significance for carcass gain, the evaluation of non-carcass components was necessary to complement the results of the present study. It is noted that the components not part of the carcass were not affected by the consumption of inoculated silages (Table 8), confirming the aforementioned carcass gain results. 
Table 7

Carcass traits of heifers finished in feedlot with inoculated corn silage

\begin{tabular}{|cccccccc|}
\hline \multirow{2}{*}{ Parameter } & \multicolumn{3}{c}{ Experimental diets } & \multirow{2}{*}{ Average } & SEM & P-value \\
\cline { 2 - 4 } & Control & 11 CFT & 11 C33 & & & \\
\hline Slaughter weight, kg & $441.3 \mathrm{~b}$ & $451.8 \mathrm{a}$ & $441.2 \mathrm{~b}$ & 444.8 & 0.6208 & 0.0001 \\
\hline Hot carcass weights, kg & $232.2 \mathrm{~b}$ & $241.2 \mathrm{a}$ & $231.2 \mathrm{~b}$ & 234.9 & 0.9011 & 0.0010 \\
\hline Carcass yield, \% & 52.62 & 53.37 & 52.43 & 52.80 & 0.1761 & 0.4220 \\
\hline Fat thickness, cm & 6.17 & 6.42 & 6.25 & 6.28 & 0.3619 & 0.8158 \\
\hline Carcass length, cm & 125 & 125 & 124 & 124 & 0.3355 & 0.2938 \\
\hline Thigh thickness, cm & 17.8 & 18.5 & 17.5 & 17.9 & 0.1300 & 0.1141 \\
\hline Arm length, cm & 35.5 & 35.8 & 35.7 & 35.7 & 0.5103 & 0.1129 \\
\hline Arm circumference, cm & 38.6 & 38.9 & 37.8 & 38.4 & 0.0282 & 0.4420 \\
\hline
\end{tabular}

Means, followed by lower case in the line differ among them by the Tukey Test at $5 \%$.

\section{Table 8}

Yield of non-carcass components, expressed as a percentage of body weight, of heifers finished in feedlot using diets with inoculated silage

\begin{tabular}{|c|c|c|c|c|c|c|}
\hline \multirow{2}{*}{ Parameter } & \multicolumn{3}{|c|}{ Experimental diets } & \multirow{2}{*}{ Average } & \multirow{2}{*}{ SEM } & \multirow{2}{*}{$P$-value } \\
\hline & Control & $11 \mathrm{CFT}$ & $11 \mathrm{C} 33$ & & & \\
\hline \multicolumn{7}{|l|}{ Vital organs } \\
\hline Heart & 0.36 & 0.34 & 0.34 & 0.35 & 0.0068 & 0.4152 \\
\hline Liver & 1.00 & 0.98 & 0.91 & 0.96 & 0.0188 & 0.3575 \\
\hline Lungs & 0.77 & 0.77 & 0.73 & 0.76 & 0.0088 & 0.0966 \\
\hline Kidneys & 0.25 & 0.24 & 0.24 & 0.24 & 0.0067 & 0.8229 \\
\hline Spleen & 0.31 & 0.28 & 0.29 & 0.29 & 0.0053 & 0.1803 \\
\hline Full rumen-reticulum & 8.25 & 7.74 & 8.2 & 8.06 & 0.1736 & 0.7638 \\
\hline Empty rumen-reticulum & 2.93 & 2.95 & 3.11 & 3.00 & 0.0770 & 0.6945 \\
\hline Full intestines & 5.33 & 5.34 & 5.54 & 5.40 & 0.0979 & 0.6708 \\
\hline \multicolumn{7}{|l|}{ External components } \\
\hline Head & 2.31 & 2.26 & 2.24 & 2.27 & 0.0212 & 0.3978 \\
\hline Tongue & 0.18 & 0.17 & 0.17 & 0.17 & 0.0028 & 0.6671 \\
\hline Skin & 9.3 & 8.77 & 8.89 & 8.99 & 0.1606 & 0.5763 \\
\hline Tail & 0.28 & 0.27 & 0.28 & 0.28 & 0.0026 & 0.0581 \\
\hline Paw & 1.90 & 1.93 & 1.88 & 1.90 & 0.0326 & 0.8126 \\
\hline
\end{tabular}

For a better understanding of the data, dispersion variables and the probability values, the table 9 presents the summary of the analysis of variance of the data presented in this study. 


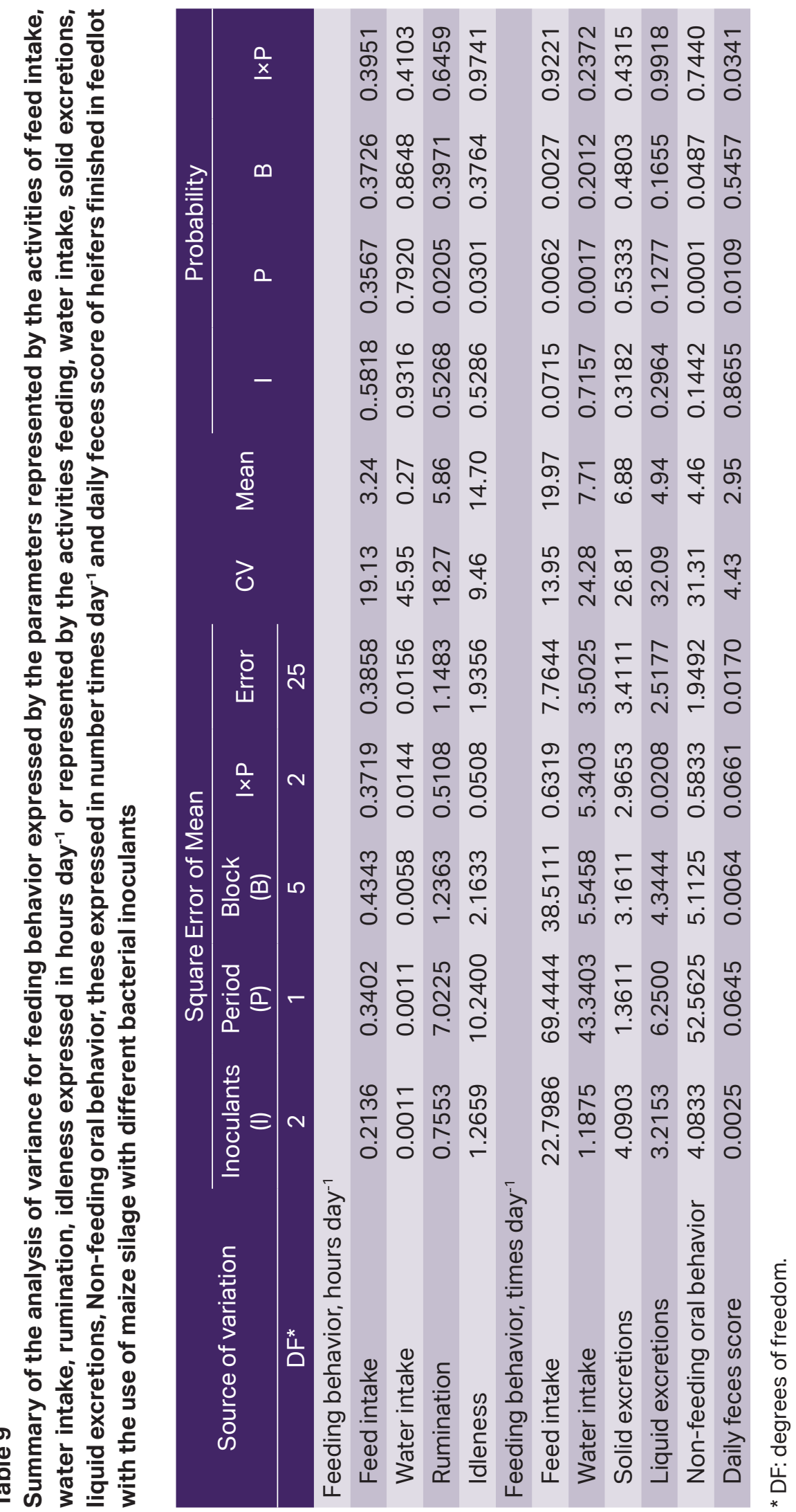




\section{Conclusions}

The addition of bacterial 11CFT and 11C33 inoculants in corn silage does not affect the ingestive behavior of the animals, but promotes improvements on the apparent digestibility of the diet in feedlot heifers. The silage with 11CFT inoculant, containing strains of Lactobacillus buchneri $(1.1 \times 1011$ CFU g- 1$)$ and Lactobacillus casei $(1.1 \times 1011$ CFU g- 1$)$, was able to increase the carcass gain during the finishing period.

\section{References}

Abdel-Rahman, M. A., Tashiro, Y., \& Sonomoto, K. (2011). Lactic acid production from lignocellulose-derived sugars using lactic acid bacteria: overview and limits. Journal of Biotechnology, 156(4), 286-301. doi: 10.1016/j.jbiotec.2011.06.017

Association of Official Analytical Chemists (1990). Official methods of analysis of AOACInternational(15nded.). Washington, DC: AOAC.

Borreani, G., Tabacco, E., Schmidt, R. J., Holmes, B. J., \& Muck, R. E. (2018). Silage review: factors affecting dry matter and quality losses in silages. Journal of Dairy Science, 101(5), 3952-3979. doi: 10. 3168/jds. 2017-13837

Ferreira, S. F., Guimarães, T. P., Moreira, K. K. G., Alves, V. A., Lemos, B. J. M., \& Souza, F. M. (2013). Caracterização fecal de bovinos. Revista Científica Eletrônica de Medicina Veterinária, 11(20), 1-22.

Filya, I., \& Sucu, E. (2010). The effects of lactic acid bacteria on the fermentation, aerobic stability and nutritive value of maize silage.
Grass and Forage Science, 65(4), 446-455. doi: 10.1111/j.1365-2494. 2010.00763.x

Fugita, C. A., Prado, I. N. D., Jobim, C. C.,Zawadzki, F., Valero, M. V., Pires, M. C. D. O.,... Françozo, M. C. (2012). Silagem de milho com e sem inoculantes enzimáticos-bacterianos sobre desempenho, características da carcaça e qualidade da carne em touros terminados em confinamento. Revista Brasileira de Zootecnia, 41(1), 154-163. doi: 10.1590/S1516-35982012000100023

Goering, H. K., \& Van Soest, P. J. (1970). Forage fiber analyses: apparatus, reagents, procedures, and some applications. (Agricultural Handbook). Washington: [s.n.].

Li, Y., \& Nishino, N. (2011). Monitoring the bacterial community of maize silage stored in a bunker silo inoculated with Enterococcus faecium, Lactobacillus plantarum and Lactobacillus buchneri. Journal of Applied Microbiology, 110(6), 1561-1570. doi: 10.1111/j.1365-2672. 2011.05010.x

Lynch, J. P., Baah, J., \& Beauchemin, D. K. A. (2015). Conservation, fiber digestibility, and nutritive value of corn harvested at 2 cutting heights and ensiledwith fibrolytic enzymes, either alone or with a ferulic acid esterase-producing inoculant. Journal of Dairy Science, 98(2), 1214-1224. doi: 10.3168/jds.2014-8 768

Missio, R. L., Brondani, I. L., Alves, D. C., Fo., Silveira, M. F. D., Freitas, L. D. S., \& Restle, J. (2010). Comportamento ingestivo de touros terminados em confinamento alimentados com diferentes níveis de concentrado na dieta. Revista Brasileira de Zootecnia, 39(7), 1571-1578. doi: 10. 1590/S1516-35982010000700025 
Nkosi, B. D., Meeske, R., Langa, T., \& Thomas, R. S. (2011). Effects of bacterial silage inoculants on whole-crop maize silage fermentation and silage digestibility in rams. South African Journal of Animal Science, 41(4), 350-359. doi: 10.4314/ sajas.v41i4.5

Oliveira, A. S., Weinberg, Z. G., Ogunade, I. M., Cervantes, A. A., Arriola, K. G., Jiang, Y.,... Adesogan, A. T. (2017). Metaanalysis of effects of inoculation with homofermentative and facultative heterofermentative lactic acid bacteria on silage fermentation, aerobic stability, and the performance of dairy cows. Journal of Dairy Science, 100(6), 4587-4603. doi: 10.3168/jds.2016-11815

Oliveira, M. R., Neumann, M., Oliboni, R., Gobetti, S. T. C., \& Faria, M. V. (2011). Use of biological addictive in ensiling of forage. Ambiência, 7(3), 589-601. doi: 10.5777/ ambiencia.2011.03.01rb

Ribeiro, E. D. A., Mizubuti, I. Y., Silva, L. D. F., Paiva, F. H. P., Sousa, C. L., \& Castro, F. A. B. (2011). Desempenho, comportamento ingestivo e características de carcaça de cordeiros confinados submetidos a diferentes frequências de alimentação. Revista Brasileira de Zootecnia, 40(4), 892-898. doi: 10.1590/ S1516-35982011 000400025
Silva, A. V., Pereira, O. G., Garcia, R., Valadares, S. D. C., Fo., Cecon, P. R., \& Ferreira, C. L. D. L. F. (2005). Composição bromatológica e digestibilidade in vitro da matéria seca de silagens de milho e sorgo tratadas com inoculantes microbianos. Revista Brasileira de Zootecnia, 34(6), 1881-1890. doi: 10. 1590/S1516-35982005000600011

Tabacco, E., Righi, F., Quarantelli, A., \& Borreani, G. (2011). Dry matter and nutritional losses during aerobic deterioration of corn and sorghum silages as influenced by different lactic acid bacteria inocula. Journal of Dairy Science, 94(3), 1409-1419. doi: 10.3168/jds.2010-3538

Van Soest, P. J., Robertson, J. B., \& Lewis, B. A. (1991). Methods for dietary fiber, neutral detergent fiber, and nonstarch polysaccharides in relation to animal nutrition. Journal of Dairy Science, 74(10), 3583-3597. doi: 10.3168/jds.S00220302(91)78551-2

Weinberg, Z. G., Shatz, O., Chen, Y., Yosef, E., Nikbahat, M., Ben-Ghedalia, D., \& Miron, J. (2007). Effect of lactic acid bacteria inoculants on in vitro digestibility of wheat and corn silages. Jornal de Ciência do Leite, 90(10), 4754-4762. doi: 10.3168/ jds.2007-0176 
